DOI: https://dx.doi.org/10.4314/sinet.v44i1.6

\title{
Assessment of Beef Meat Handling, Physicochemical and Bacteriological Properties of Selected Butcheries in Hawassa City, Ethiopia
}

\author{
Tadewos Hadero ${ }^{1,}{ }^{*}$, Gezahegn Nigusse ${ }^{1}$, and Sandip Banerjee ${ }^{2}$ \\ ${ }^{1}$ Food Science and Technology Department, Hawassa University, Hawassa, Ethiopia. E-mail: \\ tadyhad2005@gmail.com, or lujst2005@yahoo.com \\ 2 Animal and Range Sciences Department, Hawassa University, Hawassa, Ethiopia
}

\begin{abstract}
Meat is the flesh of an animal that is considered edible, especially that of a mammal or bird and is nutritionally rich in protein and allied nutrients. The carcass of an animal's pass through several channels before being consumed, even the handling of the meat by the consumers determines its nutrient availability. Fresh meats are easily contaminated during slaughtering and thereafter the processing. If not properly handled, processed and preserved, the meat is a good medium to support growth and proliferation of microorganisms. The problem of beef handling and hygiene in butchers' enterprise are focusing in slaughter slabs, beef transportation and butcheries especially in some small butchers. Over the past two decades, consumers have been exposed to a series of food safety frights including major outbreaks of food borne diseases, food security issues, and contaminated food supplies. The aim of the study is to assess the physicochemical characteristics of the beef in outlets, which includes water loss, water activity, cooking loss/ water holding capacity, $\mathrm{pH}$, shear force, moisture content and ash, and the bacteriological quality of the beef meat viz. aerobic plate count, coliform count, fecal coliform, E. coli 0157:H7 type I, S. aureus, Salmonella, and Shigella spp. The fresh beef meat samples were collected from Hawassa city randomly selected agricultural meat distributors. The laboratory analyses were done according to standard methods for the examination of foods. The results of this study revealed that the change in physicochemical properties, specifically the amount of water content decrease not only affected meat color and quality but also made meat dry and tough. However, the entire beef samples were at the food grade level. Bacteriologically meat samples were at good quality status compared to the standard set for fresh foods such as raw meat. Moreover, Salmonella and Shigella spp. in every 25 gm sample of raw beef were not detected. Environment, equipment and personnel sanitary hygiene during butchering beef meat helps to keep beef meat bacteriologically safe and quality.
\end{abstract}

\section{Keywords/phrases: Bacteriological properties, Butchers, Handling, Physicochemical properties, Beef meat}

\section{INTRODUCTION}

\section{Background and justification}

Agriculture is the cornerstone of Ethiopian economy and the overall growth of the country is ascribed to the success of the agriculture sector. The sector represents $42 \%$ of the Gross Domestic Product (GDP) of the country and about $85 \%$ of the inhabitants are directly or indirectly associated with this sector (CSA, 2015). The livestock population of the country is the largest in Africa with 60 million heads of cattle and 32 million heads each of goats and sheep. The livestock contribute $15-17 \%$ of the GDP and 35$49 \%$ of agricultural GDP, and $37-87 \%$ of the household incomes (Samson and Frehiwot, 2014). According to Adams and Moss (2005) and Zakpaa et al. (2009), edible animal flesh comprises principally the muscular tissues but also includes organs such as the heart, liver, and kidneys, among all the muscles account for the largest chunk. Water makes up $75 \%$ of muscle weight, while proteins contribute $19 \%$ of muscle weight, lipid content is the most variable of all meat constituents, making up 2.5\% (or more) of the weight, $1.5 \%$ non-protein nitrogenous compounds, $1 \%$ carbohydrate and nonnitrogenous components and $1 \%$ inorganic matter (Benjamin, 2003; Werner et al., 2004).

Physicochemically, the water in meat exists either in a bound form or in a free state. The bound water is associated with proteins through hydrogen bonds, which are influenced by the surface charge and polarity of the proteins (Januškevičienè et al., 2012). Besides, the chemical composition, meat culinary and technological value is affected by its physicochemical properties like $\mathrm{pH}$. The measurement of $\mathrm{pH}$ at different time after slaughter provides information about quality (Januškevičienè et al., 2012; Werner et al., 2004). The $\mathrm{pH}$ of cut meat or meat batter is around 5.5-6.0. The $\mathrm{pH}$ of food is critical because at low levels, it favors the growth

"Author to whom correspondence should be addressed. 
of MOLDs and yeasts. In neutral or alkaline $\mathrm{pH}$ foods such as meat and meat products, bacteria are more dominant (Werner et al., 2004). The quality of fresh meat is influenced by a large extent on its drip loss, which is technologically and economically important not only for foodprocessing industry but also for consumers (Prevolnik et al., 2010). Postmortem temperature during storage also influences the ability of the muscles to retain moisture; high temperature leads to high drip loss and shrinkage. From the economic point of view, low drip loss is extremely desirable because meat is sold by weight and any water loss leads to a reduction in yield due to loss in the total weight of the meat and significant loss of protein thus affecting the nutritive value of meat (Hoving-Bolink et al., 2005). The quality of the meat depends on the chewablity and hence the diameter of the muscle itself, wider the muscle diameter, it is difficult to chew and hence not desirable; however, the reverse is true for the cook loss (King et al., 2003). The age of the animals and the antemortam handling of the animals influence the postmortem quality of meat (Kristensen and Purslow, 2001). Trekking for longer distances lead to accumulation of lactic acid in the muscles and thereby influence the keeping quality of the meat and the cooking quality (Burrow et al., 2001). The pre-slaughter stresses of the animals also lead to deterioration in the quality of the muscles due to release of adrenalin hormones. All these coupled influence the overall quality of the meat and its keeping quality (Byrne et al., 2001).

It is generally true that the internal tissues of healthy slaughter animals are free of microbes at the time of slaughter, assuming that the animals are not in a state of exhaustion (Byrne et al., 2001). Meat and meat products are highly perishable because it is rich in nutrient source such as protein and moisture, and semi-neutral in $\mathrm{pH}$. That makes it an ideal medium for bacterial growth, spoilage, soon become unfit for human consumption and possibly leading to food borne illnesses through microbial growth, and physicochemical properties change and breakdown by endogenous enzymes leads to meat losses (Warriss, 2000). Post-harvest meat losses reduce profitability and contribute to the operators' food insecurity (MOLD, 2010). When one examines fresh meat at the retail level, varying numbers and types of microorganisms could exist. This however depends on the cleanliness of the retail outlet and that of the handler itself (Burgess et al., 2005; Werner et al.,
2004). Fresh meats are easily contaminated during slaughtering and thereafter the processing. If not properly handled, processed and preserved, the meat is a good medium to support growth and proliferation of microorganisms. A variety of sources contributes to bacteriological contamination during slaughtering, dressing, chilling and cutting processes when the muscles of animals are exposed to the environment. Sources of contamination are from multifarious sources viz. air, water, soil, feces, feed, hides, intestines, lymphnodes, processing equipment, utensils and humans (Jame et al., 2005).

Meat consumption in developing countries has been continuously increasing from a modest average annual per capita consumption of $10 \mathrm{~kg}$ in the 1960s to $26 \mathrm{~kg}$ in 2000, and will reach $37 \mathrm{~kg}$ around the year 2030 (Heinz, 2007). In many developing countries, small and medium butchers enterprises are an important component of the food supply chain that being reasonably priced and conveniently available. Besides the reasonable price and accessibility, the butcheries become public health threat nowadays. The problem of beef handling and hygiene in small and medium butchers' enterprises are focusing in slaughter slabs, beef transportation and butcheries especially in some small butchers. There is a problem of selling meat in unsanitary environment such as open shelters and unclean butchers shop, which sold in unacceptable way of meat handling. The main step towards improving the quality of beef meat is to understand slaughter process and distribution system and retail marketing in butchers' kiosk, beef handling knowledge and practice along the production chain from retail outlets.

Determination of physicochemical properties change that takes place throughout the meat supply chain was can help to minimize meat loss. Assessment of sanitary and hygienic knowledge and handling practice would contribute the outlets for meat contamination and hence recommend intervention strategies for hygienic meat handling to reduce meat losses, which cause economic loss on operators. Evaluation of microbial quality of meat would create awareness on the microbial safety of meat and propose mitigation measure to reduce meat contamination and hence meat losses. One of the major challenges facing the meat slaughter in retailing outlets is that the sanitary and hygienic knowledge and handling practice during slaughter, distribution system and retail marketing, as well as awareness on 
physicochemical and microbiological properties change takes place throughout the supply chain. However, limited studies have been conducted to assess physicochemical properties change, microbial contamination and beef handling knowledge and practice along the production chain from retail outlets in Hawassa city. Thus, this study was help to develop information on physicochemical property changes and bacteriological safety and quality of beef and hygienic and sanitary knowledge and handling practices in selected butchers of the city. The overall objective of the study was to determine handling practices, physicochemical properties, and bacteriological quality of fresh beef from collected from selected retail beef outlets in Hawasssa city.

\section{MATERIALS AND METHODS}

\section{Description of the study area}

The study was conducted in Hawassa city; the South Nations, Nationalities and People's Regional State capital, which is located at $275 \mathrm{~km}$ south of the capital Addis Ababa on the Addis Ababa-Moyale highway. The city is located on the Eastern shores of Lake Hawassa in the Great Rift Valley Zones of Ethiopia. It's geographic latitude and longitude is $07^{\circ} 03^{\prime} \mathrm{N}$ and $38^{\circ} 29^{\prime} \mathrm{E}$, respectively and elevation is 1750 masl. The current population of the city is around 436,581 of this 218,176 are male and 218,405 are female (CSA, 2013).

\section{Sample collection and sample preparation}

Preliminary survey with field observation and key informant interview were applied before sample collection to determine potential butchers shop in the city. After pre information about potential butchers shop, four major butchers' shop of most people prefers to buy, beef were randomly selected from purposively selected sites of the city. The butcherers shops were selected were around Atote, Piazza, Mobil, and Godgoada. The samples were collected at room temperature with relative humidity (is a measure of the actual moisture content of the air compared to the moisture content of saturated air at the same temperature). It is useful as an indicator of the drying capacity of the air nearly $70 \%$. Samples were collected within two hrs post-slaughter from purposively selected butchers; in order to minimize the physicochemical property and bacteriological quality changes due to environmental temperatures and post-slaughter timings. A total of $16 \mathrm{Kg}$ (from 4 site twice per day and $2 \mathrm{~kg}$ from each sample unit) fresh beef cut samples were aseptically collected from different parts of carcass in sterile polythene pouches. The samples were sealed, properly labeled and transported in icebox at a temperature between $0^{\circ} \mathrm{C}$ and 4 to prevent further contamination to the SNFST Laboratory, College of Agriculture, Hawassa University. The samples were analysed immediately upon arrival in the laboratory.

\section{Study methodology \\ Physicochemical property of beef meat \\ Determination of water loss}

Raw meat samples (1000 g) were hanged at meat hanging ladder in open condition at room temperature for $10 \mathrm{hrs}$ in each butchers shop. After $10 \mathrm{hrs}$, the samples placed in butchers shops were weighed using beam balance. The measured weight of the sample is the water loss of the sample (Diaz et al., 2010); water lost either by evaporation or drip out was calculated as follows

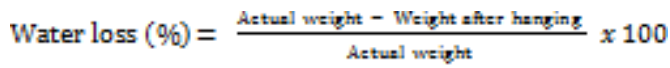

\section{Determination of cooking loss}

Cooking loss of meat was determined by using procedure described by Bouton et al. (1976). Three replicates of 5 gram each of the meat sample was freshly cut and represented by individual slices. The meat samples were placed in three test tubes and then placed in a boiling water bath for 5 mins and removed and cooled. Cook loss of meat sample was obtained by taking difference of initial and final weight.

\% Cookingloss =

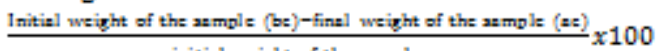
initisl weivht of the asmple (Eq. 2)

Where;

$\mathrm{bc}=$ before cooking

$\mathrm{ac}=$ after cooking

\section{Water activity}

Water activity (aw) was determined by the direct method using a Decagon hygrometer (Aqua-Lab CX2) calibrated with distilled water at 20 . 


\section{Shear force measurement}

Muscle samples were removed from each muscle for Warner-Bartzler shear force (WBSF) measurement after 4 hour post-slaughter. For each meat sample, six cylindrical cores $(1.27 \mathrm{~cm}$ diameter) perpendicular to the orientation of muscle fibers were taken and sheared by a Vshaped blade attached to the texture analyzer (Texture Analyzer, TA plus, Stable Micro Systems, Surrey, UK) using a $30-\mathrm{kg}$ load cell and a crosshead speed of $120 \mathrm{~mm} / \mathrm{min}$. The forcedeformation curves were analyzed by Texture Exponent Lite software supplied by the manufacturer. The maximum force needed to shear each core was obtained and the four replicates were used for shear force test for all samples.

\section{pH value determination}

The $\mathrm{pH}$ of the beef samples was determined using a $\mathrm{pH}$ meter (InoLab D-82362, Weliheim, Germany). Aqueous extract of $5 \mathrm{~g}$ (with accuracy of $0.01 \mathrm{~g}$ ) of minced sample was weighed. The sample was mixed with $50 \mathrm{ml}$ distilled water in $100 \mathrm{ml}$ conical flask to homogenize in order to obtain representative samples of fresh beef meat. The flask was stirred periodically for 30 mins, and then filtered. The $\mathrm{pH}$ meter first calibrated against standard buffer solutions of pH 7 (Super Enterprise 039039, Ambala Cantt, India). Afterwards, electrodes were washed with distilled water, dried with towel and soaked in an analyzed aqueous extract of meat and the $\mathrm{pH}$ value was recorded. Then, the electrode was rinsed with distilled water between tests and kept in distilled water after use (AOAC, 2005; Januškevičienè et al., 2012).

\section{Determination of moisture content}

Meat moisture content was determined by AOAC (2000). Fresh meat sample (in triplicate) was weighed on a sensitive balance. The samples were then placed on a flat bottom aluminium dish, which was placed overnight in hot oven at $105^{\circ} \mathrm{C}$. The sample was placed in dissector and allowed to cool. The dried and cooled sample was weighed on the same balance, the weight taken three times and then averaged. Moisture content was obtained through difference of initial and final weight of the sample.

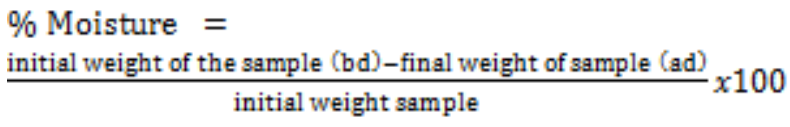

Where;

bd= before dried

ad $=$ after dried

\section{Determination of ash content}

The ash of the meat percentage was assessed using the dry ashing technique. Three samples of 0.5 grams each of fresh meat was taken in silica crucibles. The sample was transferred to a muffle furnace. The furnace was heated to $600^{\circ} \mathrm{C}$ the temperature was maintained for $6 \mathrm{hrs}$ and then after the sample was allowed to cool overnight. The cooled crucible was transferred to a dissector and the sample was weighed. Each sample was weighed thrice and the average weight was taken (AOAC, 2005) finally, it was calculated as:

$$
\% \text { ash }=\frac{\text { eight of the ash }}{\text { weight of the sample taken }} x 100
$$

\section{Bacteriological quality evaluation of meat}

Preliminary steps

Laboratory equipment, solutions, and media were sterilized by autoclaving at $121^{\circ} \mathrm{C}$ for 15 mins. All media were melted in oven at $45^{\circ} \mathrm{C}$ and placed in water bath to hold the temperature (Michael and Joseph, 2004; Roberts and Greenwood, 2003). Serial dilutions of representative homogeneous sample of fresh beef were used for determination of APC, Coliform, Fecal coliform, E. coli type I, S. aureus, Salmonella, and Shigella spp. prepared according to Midura and Bryant (2001).Using aseptic technique the initial dilution was made, a 1:10 dilution of the fresh beef by blending $10 \mathrm{~g}$ (the meat sample was weighed out using electronic balance) of the sample into dilution tube of $90 \mathrm{ml}$ sterilized $0.1 \%(\mathrm{w} / \mathrm{v})$ peptone saline solution/ MRD. Then, the dilution bottles were shaken 25 times through a $30 \mathrm{~cm}$ arc in approximately 7 second. The first dilutions were labeled as $10^{-1}$. Immediately after the first dilution was mixed, $1 \mathrm{ml}$ of it was transferred aseptically into dilution tube of $9 \mathrm{ml}$ sterilized $0.1 \%(\mathrm{w} / \mathrm{v})$ peptone saline solution/ MRD. The second dilution was labeled as $10^{-2}$. This same fashion was repeated through serial dilutions of $10^{-3}, 10^{-4}, 10^{-5}, 10^{-6}$, and $10^{-7}$. The dilution factor for such a sample is $1 / 10$, or $10-1$, and is calculated as follows: 


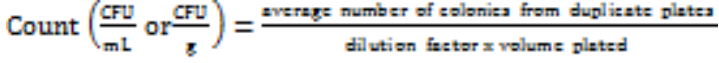

Aerobic plate count (APC)

The aerobic plate count method specifically pour plating technique was used to enumerate aerobic mesophilic bacteria in foods (Morton, 2001). An aliquot of $1 \mathrm{ml}$ of each serial dilution was transferred aseptically into sterilized and marked duplicate petri-dishes in opposite direction to the sample. As soon as possible (but not later than $20 \mathrm{~min}$ ) after placing diluted sample in Petri dishes, $15 \mathrm{ml}$ of molten to 46 plate count agar were poured on it. The sample and the media were mixed uniformly, in movements forming the number eight or in circular movements, eight to ten times clockwise and then eight to ten times counter-clockwise. The plates were inverted and then incubated at $37^{\circ} \mathrm{C}$ for $48 \mathrm{hrsbefore}$ colonies were counted and reported as colony forming units/g (cfu/g).At the end of the incubation period, all of the petridishes containing between 25 and 250 colonies (this range is considered as statistically significant) per plate were selected and counted by using Quebec colony counter (Yerco Colony Counter-Electronic, New York Scientific Instruments), all the remaining plates were discarded. The counted colonies were recorded and used in the equation 6 , in order to report computed count as SPC per $\mathrm{ml}$ of diluted sample (Mukhopadhyay et al., 2009; Roberts and Greenwood, 20003; Werner et al., 2004).

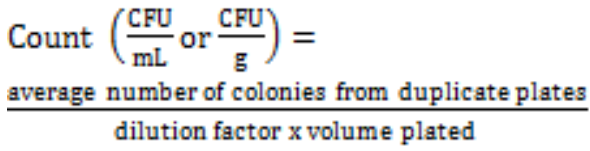

\section{Isolation and enumeration of Staphylococcus aureus}

According to Hatcher et al. (2001) and Neusely et al. (2013) isolation and enumeration of S. aureus was done by selecting the three appropriate dilutions of the sample and $0.1 \mathrm{ml}$ of each was inoculated on Baird Parker Agar (BPA), using the spread plate technique. Spread inoculum over surface of agar plate, using sterile bent glass streaking rod. The plates were retained in upright position until inoculum is absorbed by agar. The first dilution of $1 \mathrm{ml}$ and $0.1 \mathrm{ml}$ of the two subsequent dilutions (one milliliter of first dilution was distributed on four plates: $0.3 \mathrm{ml}, 0.3 \mathrm{ml}, 0.3 \mathrm{ml}$, and $0.1 \mathrm{ml}$ ) were inoculated. Plates were incubated at inverted position at $35-37^{\circ} \mathrm{C} / 45-48$ hrs. Plates were examined for typical S. aureus colonies: black or gray, small (maximum 2-3 $\mathrm{mm}$ in diameter), surrounded by an opaque halo and frequently with an outer clear halo. Non-lipolytic strains form similar colonies but without the opaque and clear halos. Plates were selected containing 20-200 colonies for counting and if more than one type of presumptive $S$. aureus colonies is present, each type was counted separately. Five typical colonies were selected for coagulase test. If there are fewer than five colonies, all were selected. If several types of presumptive $S$. aureus colonies are present, one or more colonies of each type were selected. Suspected S. aureus colonies were transferred to Brain Heart Infusion (BHI) Broth tubes and emulsified. A loopful was transferred from the Brain Hearth Infusion (BHI) tubes to Trypticase Soy Agar (TSA) slants. BHI and TSA tubes were incubated at $35-37^{\circ} \mathrm{C} / 18-24$ hrs. TSA cultures were kept at ambient temperature for other tests, if necessary.

Catalase test: A loopful TSA culture was emulsified in one drop of 3\% Hydrogen Peroxide on a glass slide. Immediate bubbling is a positive reaction. S. aureus is catalase positive. Number of S. aureus cells/g of sample was calculated based on percentage of colonies tested that are confirmed as S. aureus.

\section{Total coliform}

Total coliform count was determined according to Roberts and Greenwood (20003), Werner et al. (2004) and Hassan et al. (2010). The pour plating method was used to recover and enumerate spoilage bacteria. Dilution was shaken again from 10-1, 10-2, 10-3, 10-4, 10-5, 106 , and $10-7$ and $1 \mathrm{ml}$ was transferred aseptically into sterilized and labeled duplicate petridishes. The molten, cooled to 46 violet red bile glucose agar (VRBGA) of $15 \mathrm{ml}$ was poured aseptically to petri- dish in opposite direction to the sample. The sample and the agar was mixed by gentle swirling and allowed to set. After hardening, $5 \mathrm{ml}$ molten, cooled VRBGA to 45 was overlaid and allowed to set. The plate was allowed to solidify. After the overlay solidifies, plates were inverted and incubated at 37 for 24 hrs. Finally, to report the TCC per $\mathrm{ml}$, all countable plates between 10 and 150 colonies per plate characterized as purplish red colonies 0.5 $\mathrm{mm}$ or greater diameter, usually surrounded by a reddish zone was counted by using Quebec colony counter $220 \mathrm{Vac}, 50 \mathrm{~Hz}$ USA. The test was made in duplicate and the report was made by 
taking the mean values as single data. The counted colonies were calculated using equation 7 to report the TCC.

\section{Count $(\mathrm{CFU} / \mathrm{mL}$ or $\mathrm{CFU} / \mathrm{g})=$ average number of colonies from duplicate plates dilution factor $x$ wolume plated}

(Eq. 7).

\section{Fecal coliform}

Chromocult coliform agar (Merck, Germany) was used as a selective indicator media for the enumeration of E. coli. Inoculations of beef samples from selected dilutions were done using a procedure similar to that of APCs above. After inoculation, dark blue colonies were classified as E. coli colonies while pink colonies were classified as other coliforms such as fecal coliforms (Hatcher et al., 2001).

\section{Escherichia coli type I}

Isolation and enumeration of E. coli was done according to Roberts and Greenwood (20003). Cellulose ester membranes were placed using sterile forceps, $85 \mathrm{~mm}$ diameter and 0.45 1.2 micro meter pore size with working surface (dull side) uppermost, onto the surface of plates of a non-selective agar, care was taken to avoid trapping air bubbles beneath the membrane. The membrane surfaces were smoothed with a sterile spreader. Sufficient plates were used for the range of decimal dilutions selected for testing. One $\mathrm{ml}$ of the dilution was inoculated on to the centre of the membrane. This inoculum was spread over the whole membrane surface, using a sterile spreader, taking care not to spill over the membrane edge. The inoculums were allowed to soak in by leaving at room temperature for 15 mins. Plates were incubated with the membrane/agar surface uppermost at $37^{\circ} \mathrm{C}$ for 4 hrs. The membranes were transferred aseptically to plates of tryptone bile agar (do not smooth over the membrane surface). The plates were incubated at 44 for $21 \mathrm{hrs}$ and not inverted. The Petri- dish lid was removed, and $2 \mathrm{ml}$ of Vracko and Sherrisindole reagent $(5 \% \quad \mathrm{p}$ dimethylaminobenzaldehyde in $1 \mathrm{M}$ hydrochloric acid) was placed in the lid. The membrane was removed from the agar surface and it was lowill bed on to the indole reagent so that the whole of the lowill bed surface of the membrane was wetted. The excess indole reagent was pipetted off after 5 mins. The in dole reaction was developed by exposing the treated membrane to strong sunlight or ultraviolet light (366nm) for 30 mins. The number of pink-red (indole positive) colonies were counted, plates containing up to 150 pink colonies were selected, and the level of E. coli per $g$ of sample was calculated.

\section{Salmonella}

Sample of $25 \mathrm{~g}$ was aseptically weighed into sterile blending container. Sterile lactose broth of $225 \mathrm{ml}$ was aseptically added and blended for 2 mins and homogenized mixture was transferred to sterile wide-mouth, screw-cap jar (500 ml) container and let stand 60 mins at room temperature with jar securely capped. The sample was mixed well by swirling and $\mathrm{pH}$ was determined with test paper. $\mathrm{pH}$ was adjusted, if necessary, to 6.8. Steamed (15 mins) Tergitol Anionic 7 was added up to $2.25 \mathrm{ml}$ and mixed well. Steamed (15 min) Triton X-100 was used alternatively. The use of these surfactants was limited to minimum quantity needed to initiate foaming. Actual quantity depends on composition of test material. Surfactants were not needed in analysis of powdered glandular products. Jar caps was loosen $1 / 4$ turn and sample mixtures were incubated for $24 \mathrm{hrs}$ at $35^{\circ} \mathrm{C}$. Incubated sample was tighten lid and gently shaken. Mixture of $0.1 \mathrm{ml}$ transferred to 10 $\mathrm{ml}$ Rappaport-Vassiliadis (RV) medium and another $1 \mathrm{ml}$ mixture to $10 \mathrm{ml}$ tetrathionate (TT) broth. Rappaport-Vassiliadis medium was incubated for $24 \mathrm{hrs}$ at $42^{\circ} \mathrm{C}$ (circulating, thermostatically-controlled, water bath). Tetrathionate broth was incubated for $24 \mathrm{hrs}$ at $43^{\circ} \mathrm{C}$ (circulating, RV medium was repeated with $3 \mathrm{~mm}$ loopful $(10 \mu \mathrm{l})$ of (for samples of high microbial load foods). Plates were incubated for 24 hour at $35^{\circ} \mathrm{C}$. Plates were examined for presence of colonies of Salmonella (Kinsella et al., 2008; Roberts and Greenwood, 2003).

Shigella spp.

Sample of $25 \mathrm{~g}$ aseptically was added to 225 $\mathrm{ml}$ Shigella broth without novobiocin and blended according to BAM procedures. The diluted sample directly from the blender was 0.1 $\mathrm{ml}$ spread-plated onto each of 2 MacConkey agar plates. The dilution 10-1 - 10-7 was made tenfold from blender in Butterfield's buffer and $0.1 \mathrm{ml}$ was spread on each of 2 MacConkey plates. Additional dilutions may be plated, depending on level of microbial contaminants suspected and health hazard concern with specific pathogen. Plates were incubated for 18-24 hrs at 35-37 .Growth--presence/absence method: 
Sample of $25 \mathrm{~g}$ was aseptically added to $225 \mathrm{ml}$ Shigella broth without novobiocin contained in sterile $500 \mathrm{ml}$ Erlenmeyer flask. The sample contents were shaken at $37^{\circ} \mathrm{C}$ for 24 hrs. The aliquot of $0.1 \mathrm{ml}$ was withdrawn at 0,4 , and 24 hrs, diluted in diluent buffer and $0.1 \mathrm{ml}$ of diluted cultures was spread onto MacConkey agar plates. If total aerobic plate count was desired, also plated onto trypticase soy agar (TSA) and incubated at $37^{\circ} \mathrm{C}$ overnight.

\section{Data management and analysis}

One-way analyses of variance (ANOVA) were used on the data to examine the effect of four butchers, their interaction and surroundings, followed by Multiple Range Test at significance level of $\mathrm{p} \leq 0.05$ percentages, using the Statistical Analysis System (SAS) software. Bacteriological counts were represented as $\log 10 \mathrm{cfu} / \mathrm{ml}$. The results were presented as mean \pm standard deviation at duplicate measurements.

\section{RESULTS AND DISCUSSIONS}

\section{Physicochemical properties of beef meat Water loss}

Water loss may occur in two stages. First is lost as drip and second is lost by evaporation. Water loss contributes to moisture content loss in beef and causes color change in meat. As meat loses more water during storage or cooking, the meat becomes drier and tougher. In all sample points, $1 \mathrm{Kg}$ beef sample was collected and transported to Hawassa University Food Chemistry and Food Microbiology laboratory and equivalent amount of beef samples were hanged as usual in each butcher's shop beef hanging ladder. After 10hrs stay, the samples hanged in butchers shop were measured and the loss was calculated. Water loss of beef collected from Mobil (M1 and M2) (3.71\%) and Piazza (P1 and P2) (12.48\%) had significantly different, however, samples collected from Atote (A1 and A2) (8.37\%) and Godgoada (G1 and G2) (8.29\%) had no difference. Water loss of piazza is higher than the entire samples; this might be due to the use of high kilowatt electric bulb in the butcher's shop, the shop size and the front of shop exposed to sunlight.

\section{Water activity}

Fresh meat has a water activity close to one, while below 0.6 most biological reactions cease. The lower the water content, the lower the water activity of the food. Water activity of all beef samples collected from different butchers shop was not significantly difference at p 0.05 (Table 1.1). Water activity value ranged from 0.86 to 0.92 . Thus, the finding of this study indicated that all meat samples are at fresh status in the free available water for the microbial growth.

\section{Cooking loss}

Cooking loss is considered as the most important technological properties from the economic point of view, it reflects the water holding capacity of meat. As indicated in table 1.1, the average cooking loss value obtained for beef samples collected in the morning as fast as slaughtered, M1 and P1 had no significance difference similarly A1 and G1 as well. Samples collected in the afternoon from M2, G2 and P2 were not different from one another. However, samples collected in the morning (A1, M1, G1 and P1) and in the afternoon (A2, M2, G2 and P2) had significant difference at $\mathrm{p} \quad 0.05$. The highest cooking loss recorded for the sample collected from godgoada (33.37) in the afternoon, while the least value recorded was for the sample collected from A1 (atote) (13.69) in the morning. Meat loss during cooking measures the decrease in edible meat mass for human consumption (Gustavson et al., 2011). 
Table 1.Physicochemical properties of raw beef meat.

\begin{tabular}{|c|c|c|c|c|c|c|c|c|c|c|}
\hline \multirow[t]{2}{*}{ Treatment } & \multirow[t]{2}{*}{$\mathbf{N}$} & \multicolumn{9}{|l|}{ Parameters } \\
\hline & & $\begin{array}{l}\text { Water } \\
\text { loss/gm }\end{array}$ & $\begin{array}{l}\% \quad \text { Moisture } \\
\text { content }\end{array}$ & $\begin{array}{l}\text { Water } \\
\text { Activity }\end{array}$ & $\begin{array}{l}\% \text { Cook } \\
\text { loss }\end{array}$ & ng & $\begin{array}{l}\% \text { Ash } \\
\text { content }\end{array}$ & $\mathrm{pH}$ & & $\begin{array}{l}\text { Shear/compr } \\
\text { ession force } \\
(\mathrm{N})\end{array}$ \\
\hline Atote (A1) & 2 & $1032 \pm 0^{c}$ & $71.58 \pm 0.09^{\mathrm{ab}}$ & $0.87 \pm 0.04^{a}$ & $\begin{array}{l}13.69 \\
2.83^{c}\end{array}$ & \pm & $1.02 \pm 0.07^{a}$ & $\begin{array}{l}6.36 \\
0.34^{\mathrm{b}}\end{array}$ & \pm & $45.72 \pm 0.39^{b}$ \\
\hline Atote (A2) & 2 & $945 \pm 0^{\mathrm{f}}$ & $61.91 \pm 13.25^{b}$ & $0.87 \pm 0.01^{\mathrm{a}}$ & $\begin{array}{l}23.30 \\
\pm 1.03^{b}\end{array}$ & & $1.19 \pm 0.05^{\mathrm{a}}$ & $\begin{array}{l}6.50 \\
0.00^{\mathrm{b}}\end{array}$ & \pm & $39.66 \pm 0.40^{\mathrm{d}}$ \\
\hline Mobil (M1) & 2 & $976 \pm 0^{\mathrm{d}}$ & $73.30 \pm 0.42^{\mathrm{ab}}$ & $0.88 \pm 0.09^{a}$ & $\begin{array}{l}22.83 \\
1.88^{\mathrm{b}}\end{array}$ & \pm & $1.20 \pm 0.08^{a}$ & $6.50 \pm$ & & $36.41 \pm 1.45^{\mathrm{e}}$ \\
\hline Mobil (M2) & 2 & $940 \pm 0 g$ & $75.33 \pm 0.10^{\mathrm{a}}$ & $0.86 \pm 0.00^{\mathrm{a}}$ & $\begin{array}{l}30.27 \\
1.02^{\mathrm{a}}\end{array}$ & \pm & $1.21 \pm 0.10^{\mathrm{a}}$ & $\begin{array}{l}6.57 \\
0.00^{\mathrm{b}}\end{array}$ & \pm & $32.27 \pm 0.15^{f}$ \\
\hline $\begin{array}{l}\text { Godgoada } \\
\text { (G1) }\end{array}$ & 2 & $1058 \pm 0^{a}$ & $68.88 \pm 3.98^{\mathrm{ab}}$ & $0.90 \pm 0.03^{a}$ & $\begin{array}{l}17.24 \\
1.63^{c}\end{array}$ & \pm & $1.15 \pm 0.12^{\mathrm{a}}$ & $\begin{array}{l}6.49 \\
0.01^{b}\end{array}$ & \pm & $42.80 \pm 0.40^{c}$ \\
\hline $\begin{array}{l}\text { Godgoada } \\
\text { (G2) }\end{array}$ & 2 & $971 \pm 0^{e}$ & $71.77 \pm 2.04^{\mathrm{ab}}$ & $0.88 \pm 0.14^{\mathrm{a}}$ & $\begin{array}{l}33.37 \\
\pm 0.94^{\mathrm{a}}\end{array}$ & & $1.27 \pm 0.20^{a}$ & $\begin{array}{l}7.01 \\
0.27^{a}\end{array}$ & \pm & $49.15 \pm 1.49^{a}$ \\
\hline Pizaa (P1) & 2 & $1054 \pm 0^{\mathrm{b}}$ & $75.33 \pm 0.10^{\mathrm{a}}$ & $0.90 \pm 0.01^{\mathrm{a}}$ & $\begin{array}{l}25.47 \\
1.91^{\mathrm{b}}\end{array}$ & \pm & $1.30 \pm 0.17^{a}$ & $\begin{array}{l}6.58 \\
0.01^{b}\end{array}$ & \pm & $33.78 \pm 0.60^{f}$ \\
\hline Pizaa (P2) & 2 & $923 \pm 0^{\mathrm{h}}$ & $71.76 \pm 0.13^{\mathrm{ab}}$ & $0.92 \pm 0.06^{\mathrm{a}}$ & $\begin{array}{l}32.82 \\
2.14^{\mathrm{a}}\end{array}$ & \pm & $1.06 \pm 0.22 \mathrm{a}$ & $\begin{array}{l}6.49 \\
0.02^{\mathrm{b}}\end{array}$ & \pm & $32.20 \pm 0.06^{\mathrm{f}}$ \\
\hline
\end{tabular}

A1: Morning sample from Atote; A2: Afternoon sample from Atote; M1: Morning sample from Mobil; M2: Afternoon sample from Mobil; G1: Morning sample from Godgoada; G2: Afternoon sample from Godgoada; P1: Morning sample from Pizaa; P2: Afternoon sample from Pizaa; Mean = Mean SD; Mean with the same letter in the same column is not significantly different at CI of 95\% where $a$ is significantly higher than $b$.

\section{Shear force measurement}

Beef samples collected in the morning and afternoon from different butchers shop were measured for shear force, which was ranged from 32.20 to 49.15 (Table 1.1). Sample collected in the morning and afternoon from piazza (P1 and P2) butchers shop had no difference, while the rest entire samples collected in the morning and afternoon had significantly different at $p$ 0.05 . Shear force decreased in every cut during aging, which means there is an increase in tenderness, however for G1 (42.80) and G2 (49.15) the reverse is true. This might be due to the measurement error.

$p H$

Measuring $\mathrm{pH}$ gives important information about color and water-holding capacity of the meat and is a key determinant of meat quality. Table 1.1 represented the average $\mathrm{pH}$ value of meat samples collected at $2 \mathrm{hrsand} 10$ hrspostmortem. $\mathrm{pH}$ of entire beef samples collected from different sites of the city had no significant difference from each other except godgoada( $\mathrm{pH}$ value of 7.01).But the $\mathrm{pH}$ values varied from 6.36-7.01 after $10 \mathrm{hrs}$ post- slaughter. The present findings showed poor handling of cattle as $\mathrm{pH}$ is higher, compared with handled under good conditions ( $\mathrm{pH}=5.4$ - 5.8) (Strappini, 2009). This could be due to decrease in moisture content of beef as of storage time and condition.

\section{Moisture content}

As shown in Table 1.1, average moisture content of beef sample collected in the morning from piazza (75.33) were significantly different (p 0.05) from samples collected in the morning from A1, M1 and G1. Moisture content of samples collected in the morning varies to some extent from samples collected in the afternoon except G1 and G2. The highest moisture content was showed for piazza (75.33), which might be due to similar reason with that of water loss.

\section{Ash content}

Ash content is the measure of the total content of mineral salts in a food. The mean ash content of beef samples collected in the morning and afternoon from different butchers shop of the city were not significantly different ( $p$ 5) as revealed in the table 1.1. The ash content of meat is normally about $1 \%$, so the result of this finding is agreed with this general truth.

\section{Bacteriological characteristics of beef meat \\ Aerobic Mesophilic plate count (APC)}

The total aerobic mesophilic plate count, usually called aerobic plate count or standard plate count, is the most commonly used general indicator of bacterial populations, hygienic condition during food production, transportation 
and storage, and ultimately quality of food. Mean APCs of all beef samples collected from different butchers were not significantly different at p 0.05 (Table 1.2). The highest mean APC of this study was recorded for $G=7.07 \log 10 \mathrm{cfu} / \mathrm{g}$, while the least was for $A=5.21 \log 10 \mathrm{cfu} / \mathrm{g}$, which is lower than the finding reported by Ahmad et al. (2013), the assessment of microbial load of raw meat at abattoirs and retail outlets (7.15, $\log 10 \mathrm{cfu} / \mathrm{g}$ ) studied in Lahore city, Nigeria. As compared to the report of Labore city, Nigeria, the finding of this study indicates good transportation system and storage conditions of raw beef meat. Thus, according to the International Commission on Microbiological Specifications for Foods (< $7 \log 10 \mathrm{cfu} / \mathrm{g}$ ) (ICMSF, 2011), APC of $75 \%$ of analyzed samples not exceeded $107 \mathrm{cfu} / \mathrm{g}$, whereas $25 \%$ of the samples a little bit exceeded the limit, however most bacteria do not grow at water activities below 0.91 .

\section{Total coliform}

A coliform count on fresh product is a good indication of whether sanitary methods were used in processing and handling, and they are closely associated with the presence of pathogens but not necessarily pathogenic themselves. As shown in the table 1.2, entire samples collected from different butchers shop had no significant difference at $\mathrm{p}$ 0.05. The mean total coliform count for $75 \%$ sample beefs were exceeded the acceptable limit $(<4$ log 10 cfu/g) specified by the ICMSF (2011), while 25\% was under the maximum limit. This might be due to inferior sanitary condition during sample collection, handling, and temperature during transportation and supportive environment of retail outlets for the microbial growth.

\section{Fecal coliform and Escherichia coli type I}

Both fecal coliform and E. coli count are the most common contaminants of food items that also considered as an indicator of food quality (Alam et al., 2010). The detection of E. coli was an indicator of fecal contamination, and on the assumption that pathogens associated with meat are mainly of fecal origin. In current study, fecal coliform and E. coli had been found in all meat samples collected from different butchers shop both morning and afternoon were not significantly different (Table 1.2). This result was similar to the finding of Ahmad et al. (2013) and Ali et al. (2010). Fecal coliform and E. coli type I were present in 50\% samples of retail outlets were higher than established limits in guidelines (ICMSF (2011) (< $4 \log 10 \mathrm{cfu} / \mathrm{g})$. The reason behind is similar to total coliform count expressed above.

Table 2. Bacteriological characteristics of beef meat.

\begin{tabular}{|c|c|c|c|c|c|c|c|c|c|c|}
\hline \multirow{3}{*}{$\begin{array}{l}\text { Treatment } \\
\text { Atote }(\mathrm{A})\end{array}$} & \multirow{3}{*}{$\begin{array}{l}\mathbf{N} \\
2\end{array}$} & \multicolumn{9}{|c|}{ Parameters } \\
\hline & & \multicolumn{2}{|c|}{$\begin{array}{l}\text { APC } \\
(\log 10 \mathrm{cfu} / \mathrm{g})\end{array}$} & \multicolumn{2}{|c|}{$\begin{array}{l}\text { Coliform } \\
(\log 10 \mathrm{cfu} / \mathrm{g})\end{array}$} & \multicolumn{2}{|c|}{$\begin{array}{l}\text { Fecal coliform } \\
(\log 10 \mathrm{cfu} / \mathrm{g})\end{array}$} & \multicolumn{2}{|c|}{$\begin{array}{l}\text { E.coli type I } \\
(\log 10 \mathrm{cfu} / \mathrm{g})\end{array}$} & $\begin{array}{l}\text { S. aureus } \\
(\log 10 \mathrm{cfu} / \mathrm{g})\end{array}$ \\
\hline & & 5.21 & $+2.06^{a}$ & 3.41 & $2.73^{a}$ & 3.24 & $2.49^{a}$ & 1.48 & $2.49^{a}$ & 1.00 \\
\hline Mobil (M) & 2 & 6.16 & $0.73^{a}$ & 4.47 & $2.22^{a}$ & 4.32 & $2.07^{a}$ & 4.32 & $2.07^{a}$ & 1.00 \\
\hline Godgoada (G) & 2 & 7.07 & $0.94^{\mathrm{a}}$ & 4.62 & $2.01^{\mathrm{a}}$ & 4.50 & $2.00^{\mathrm{a}}$ & 4.50 & $2.00^{\mathrm{a}}$ & 1.00 \\
\hline
\end{tabular}

APC: Aerobic Plate Count; E.coli = Escherichia coli; S. aureus = Staphylococcus aureus; Mean = Mean SD; Mean with the same letter in the same column is not significantly different at CI of 95\%, where a is significantly higher than b. Salmonella and Shigella spp. Were not islated

\section{Staphylococcus aureus count}

S. aureusis a pathogenic microorganism that may cause infections as well as foodborne intoxications. In present study, mean S. aureus counts for the beef samples collected both morning and afternoon from retail outlets was one $\log 10 \mathrm{cfu} / \mathrm{g}$ (Table 1.2), which was not significantly different from entire samples. The finding of this study is lower than the report of Francis et al. (2015)(4.77 - 5.50log $10 \mathrm{cfu} / \mathrm{g})$ the study conducted in Accra, Ghana. The result was alos with in the limit of acceptable based on the standards. This study finding may indicate the good sanitary quality of raw beef compared to the finding reported in Accra city.

\section{Salmonellae and Shigella spp. detection}

Salmonella and Shigella spp. were not detected in all samples collected in the morning and afternoon from different butchers shop. This is in agreement with the report of Ejeta et al. (2004), finding from retail raw meat samples in 
Addis Ababa, Ethiopia. Absence of Salmonella and Shigella spp. in every $25 \mathrm{gm}$ sample of raw beef indicates good standards of slaughtering, sanitary environmental conditions and noncontaminated feed and water compared to study finding reported in Addis Ababa.

\section{CONCLUSION AND RECOMMENDATIONS}

The findings of this study have revealed that physicochemical properties of raw beef meat collected in the morning and afternoon from different butchers shop were at standard level specified for fresh food commodities except $\mathrm{pH}$. The decrease in $\mathrm{pH}$ makes the beef slightly acidic and tough. The bacteriological load of raw beef meat is was nearly equal to the standard set for fresh produce however, $25 \%$ of APC and $75 \%$ of coliform to some extent exceeded the acceptable limit, which can be attributed to unsanitary conditions in handling in butchers shop. Environmental and equipment sanitation and personal hygiene during butchering beef meat plays a major role in beef meat safety and quality. It is recommended that butchers have to be well oriented about shops sanitation and personal hygiene. Moreover, further study should be conducted using all butchers shop could be part of as the universe of the study and the sampling process to be twice per day for three different days in different seasons is more preferable or more.

\section{ACKNOWLEDGMENT}

This study was funded by the NORAD Project of Hawassa University. The authors would like to thank the owners of butcher shops of Hawassa City. Special thanks to Mr. Endale Elisho for his laboratory assistance.

\section{REFERENCES}

1. Adams, M. and Moss, M. (2005). Food Microbiology. 2nd ed. Published by the Royal Society of Chemistry. Cambridge, UK. Pp.134-140.

2. Ahmad, M. , Sarwar, A., Najeeb, M. , Nawaz, M., Anjum, A., Ali, M. and Mansur, N. (2013).Assessment of microbial load of raw meat at abattoirs and retail outlets. The Journal of Animal and Plant Sciences 23:745-748 ISSN: 1018-7081.

3. Alam, M., Rahman, M., Siddiqu, M., Khan, P., Rand, M. and Rahman, M. (2010). Antibiogram and plasmid profiling of E. coli isolates. Journal of Biological Research 3: 1-7.

4. Ali, N., Farooqui, A., Khan, A., Khan, A., and Kazmi, S. (2010). Microbial contamination of raw meat and its environmentin retail shops in Karachi, Pakistan. J. Infect. Develop. Countries 4: 382-388.

5. Association of Official Analytical Chemists (AOAC). (2000). Official Method of Analysis (OMA) of AOAC International.16th ed. Washington, DC.(Symposium. Plant breeding): pp491-494.

6. Association of Official Analytical Chemists (AOAC). (2005). Official Methods of Analysis (OMA) of AOAC International. 18 $18^{\text {th }}$ ed. Gaithersburg, USA. Retrieved from http:/ / eoma.AOAC.org.

7. Benjamin, C. (2003). Encyclopaedia of food sciences and nutrition. Academic press. Johns Hopkins University Center for Human Nutrition School of Hygiene and Public Health Baltimore, Maryland, USA.Pp.37573817.

8. Bouton, P., Harris, P. and Shorthose, W. (1976). Dimensional changes in meat during cooking. Journal of Texture Studies 7:179-192.

9. Burgess, F., Little, C., Allen, G., Williamson, K. and Mitchelli, R. (2005). Prevalence of Campylobacter, Bacillus cereus, and Escherichia coli on the external packaging of raw meat. Journal of Food Prot. 68: 469-75.

10. Burrow, H., Moore, S., Johnston, D., Barendse, W. and Bindon, B. (2001). Quantitative and molecular genetic influences on properties of beef: a review. Australian Journal of Experimental Agriculture 41:893-919.

11. Byrne, D., Bredie, W.. and Bak, L. (2001). Sensory and chemical analysis of cooked porcine meat patties in relation to warmed-over flavor and pre-slaughter stress. Meat Science 59: 229-249.

12. Diane, R. and Melody, G. (2003). Practical Food Microbiology. 3rd ed. Blackwell Publishing Ltd. Massachusetts, USA. Pp.96-191.

13. Diaz, O, Rodríguez, L, Torres, A. and Cobos, A. (2010). Chemical composition and physicochemical properties of meat from capons as affected by breed and age. Spanish J. Agric. Res. 8:91-99.

14. Ejeta, G., Berihun Molla, Alemayehu Daniel and Anne, C. (2004). Salmonella serotypes isolated from minced meat beef, mutton and pork in Addis Ababa, Ethiopia. Revue Méd.Vét. 155:547-551.

15. Food and Drug Administration (FDA). (2001). Bacteriological analytical manual (8thed.). Revision A, 1998. Center for food safety and applied nutrition. FDA, Rockville, MD. Hypertext updated by $\mathrm{rim} / \mathrm{cjm} / \mathrm{kwg} 2002-$ JAN-24.

16. Francis, A., Abraham Adu-Gyamfi and Victoria, A. (2015). Microbiological and parasitological quality of local beef retailed in Accra and 
radiation sensitivity of Salmonella sp. International Journal of Current Microbiology and applied Science 4: 86-96.

17. Gustavson, J, Cederberg, C, Sonesson, U, van Otterdijk, R., and Meybeck, A. (2011). Global Food Losses and Food Waste. Rome, Italy: Food and Agriculture Organization of the United Nations

18. Hatcher, W., Parish, M., Weihe, J., Splittstoesser, D. and Woodward, B. (2001). Fruit beverages. In Downes, F.P. and K. Ito, (Eds). Compendium of Methods for the Microbiological Examination of Foods (4th ed., Chapter 58, pp. 565-568). American Public Health Association. Washington, DC, USA.

20. Heinz, G., and Hautzinger, P. (2007). Meat processing technology for small- to mediumscale producers. Food and Agriculture Organization of the United Nations (FAO). Rome, Italy

21. Hoving-Bolink, A., Vedder, H., Merks, J., de Klein, W.., Reimert, H.., Frankhuizen, R., van den Broek, W. and Lambooij en, E. (2005). Perspective of NIRS measurements early post mortem for prediction of pork quality. Meat Science 69: 417-423.

22. Huff-Lonergan, E. (2009). Fresh meat waterholding capacity. In J.P. Kerry et al. (Eds) Improving the sensory and nutritional quality of fresh meat (147-157. 91). Cambridge: Woodhead Publishing Limited.

23. Huff-Lonergan, E. and Lonergan, S. (2005). Mechanisms of water-holding capacity of meat: The role of postmortem biochemical and structural changes. Meat Science 71:194204.

24. International Commission on Microbiological Specifications for Foods (ICMSF) (ed.). (2011). Microorganisms in Foods 8: Use of Data for Assessing Process Control and Product Acceptance. New York, Springer: Author.

25. Jame, M. , Martin, J. and David, A. (2005). Modern Food Microbiology (7thed.).Food Science Text Series. Publisher Spinger Science + Business Media, Inc. New York, USA. Pp.6366

26. Januškevičienè, G., Zaborskienè, G. and Kabašinskienè, A. (2012).Evaluation of meat physical, chemical and technological quality. Kuriame Lietuvosateitj. Europos Sajunga, Germany. Pp1-37.

27. King, D., Dikeman, M., Wheeler, T., Kastner, C. and Koohmaraie, M. (2003). Chilling and cooking rate effects on some myofibrillar determinants of tenderness of beef. Journal of Animal Science 81:1473-1481.

28. Kinsella, K., Prendergast, D., McCann, M., Blair, I., McDowell, D. and Sheridan, J. (2008). The survival of Salmonella entericaserovarty phymurium DT104 and total viable count son beef surface at different relative humidity and temperatures. Journal of Applied Microbiology 106:171-180.

29. Kristensen, L. and Purslow, P. (2001). The effect of ageing on the water-holding capacity of meat/pork: role of cytoskeletal proteins. Meat Science 58:17-23.

30. Michael, H. and Joseph, F. (2004). Standard methods for the examination of food products (17thed.). American Public Health Association. Washington, DC, USA. Pp.153226. Retrieved from http://www.apha.org.

31. Midura, T. and Bryant, R. (2001). Sampling plans, sample collection, shipment, and preparation for analysis. In F.P. Downes and K. Ito (Eds), Compendium of Methods for the Microbiological Examination of Foods (4th ed., chapter. 2, pp. 13-23).American Public Health Association. Washington, DC, USA.

32. MOLD (2010). An overview of livestock sub-sector in Kenya. Perspectives, opportunities and innovations for market access for Pastoral producers. Retrieved from http://africa. procasur.org/wp-content/uploads/ downloads/2014/02/.

33. Morton, R. (2001). Aerobic plate count.In F.P. Downes and K. Ito, (Eds).Compendium of Methods for the Microbiological Examination of Foods (4th ed., chapter. 6, pp. 6367).American Public Health Association. Washington, DC, USA.

34. Mukhopadhyay, H., Pillai, R., Pal, U. and AjayKumar, V. (2009). Microbiological Quality of Fresh Chevon and Beef in Retail Outlets of Pondicherry. Tamilnadu Journal of Veterinary and Animal Sciences 5:33-36.

35. Neusely, D., Marta, H., Valéria, C. , Neliane, F., Maristela, D. and Renato, A. (2013). Microbiological Examination Methods of Food and Water: A Laboratory Manual. London, UK: Institute of Food Technology ITAL, Campinas, SP, Brazil, Taylor and Francis Group.

36. Prevolnik, M., Čandek-Potokar, M. and Škorjanc, D. (2010). Predicting pork water-holding capacity with NIR spectroscopy in relation to different reference methods. Journal of Food Engineering 98:347-352.

37. Samson, L. and Frehiwot, M. (2014). Spatial analysis of cattle and goat population in Ethiopia: growth trend, distribution and market access. In Springer plus. Published online Jun 24, 2014.doi: 10.1186/2193-1801-3310 .

38. Strappini, A. (2009). Origin and assessment of bruises in beef cattle at slaughter. Animal Science 3:728-736.

39. The federal democratic republic of Ethiopia Central Statistical Agency (CSA) (2013). Population Projection of Ethiopia for All Regions at 
District Level from 2014- 2017. August 2013. Pp.61-79. Addis Ababa, Ethiopia.

40. The federal democratic republic of Ethiopia Central Statistical Agency (CSA). (2015). Livestock Characteristics. The annual agricultural sample surveys (AgSS), country summary. Addis Ababa, Ethiopia. S.G1, the annual statistical bulletins of AgSS. Pp.2-12.

41. Warriss, P. (2000). Meat Science: an Introductory Text. New York: CABI Publishing,

42. Warriss, P. (1992). Animal welfare: handling animals before slaughter and the consequences for welfare and product quality. Meat Focus International, July: 135138.

43. Werner, K. , Carrick, D. and Michael, D. (2004). Encyclopaedia of meat science. Roskilde, Denmark: Danish Meat Research Institute. Pp. 700- 729.

44. Zakpaa, H.., Imbeah, C. And Mak-Mensah, E. (2009). Microbiological characterization of fermented meat product on some selected markets in the Kumasi metropolis, Ghana. African Journal of Food Science 3:340-346. 